\title{
VERTICAL STRUCTURE OF THE ARBOREAL COMPONENT UNDER REGENERATION PHASE OF A DECIDUOUS FOREST FRAGMENT, SANTA CATARINA STATE, BRAZIL ${ }^{1}$
}

\author{
Welington Kiffer de Freitas ${ }^{2 *}$ and Luis Mauro Sampaio Magalhães ${ }^{3}$
}

\footnotetext{
${ }^{1}$ Received on 16.10.2014 accepted for publication on 07.03.2016.

${ }^{2}$ Universidade Federal Fluminense, Centro Tecnológico, Escola de Engenharia Industrial Metalúrgica de Volta Redonda, Volta Redonda, RJ - Brasil. E-mail: <wkfreitas@gmail.com>.

${ }^{3}$ Universidade Federal Rural do Rio de Janeiro, Instituto de Florestas, Departamento de Ciências Ambientais, Seropédica, RJ - Brasil. E-mail:<1.mauro@terra.com.br>.

*Corresponding author.
}

\begin{abstract}
The objective of this study was to evaluate the structure (horizontal and vertical) of a Deciduous Forest, located between the municipalities of Piratuba and Ipira (SC). $14.000 \mathrm{~m}^{2}$ of tree communities were analyzed, sub- divided into 14 plots of $10 \times 100 \mathrm{~m}$, where all individuals with DBH equal to or greater than $4.0 \mathrm{~cm}$ were sampled and identified. For natural regeneration were sampled $560 \mathrm{~m}^{2}$, divided into 14 plots of $10 \times 4 \mathrm{~m}$. In the tree strata were sampled 2.125 individuals belonging to 34 families, 80 genera and 113 species with a total density of 1.517 ind.ha ${ }^{-1}$. Natural regeneration were sampled 196 individuals belonging to 24 families and 49 species with a total density of 3.500 ind . ha ${ }^{-1}$. Luehea divaricata Mart., Actinostemon concolor (Spreng) Müll. Arg. and Parapiptadenia rigida (Benth.) Brenan had of value of increased importance (7,1\%, 7,0 \% and 5,3\%, respectively). Actinostemon concolor got high value Relative Natural Regeneration $(18,1 \%)$. The low percentage of natural regeneration of species as Luehea divaricata and Parapiptadenia rigida, respectively $3,7 \%$ and $1,5 \%$, typical of EDF , may represent a maintenance commitment in the community. The study revealed the presence of exotic species with invasive potential, as Hovenia dulcis Thumb. These facts point to the importance of the adoption of management measures, since the forest fragment studied is advancing successional terms, however, anthropogenic interference with signals in the floristic composition. These facts point to the importance of the adoption of management measures, since the forest fragment studied is suffering anthropogenic impact, influencing the ecological succession mechanisms.
\end{abstract}

Keywords: Phytosociology; Forest ecology; Secondary succession.

\section{ESTRUTURA VERTICAL DO COMPONENTE ARBÓREO EM FASE DE REGENERAÇÃO DE UM TRECHO DE FLORESTA DECIDUAL, SC}

\begin{abstract}
RESUMO-O objetivo deste trabalho foi avaliar a estrutura (horizontal e vertical) de um trecho de Floresta Estacional Decidual, localizado entre os municipios de Piratuba e Ipira (SC). Foram analisados $14.000 \mathrm{~m}^{2}$ do estrato arbóreo, sub-divididos em 14 parcelas de $10 \times 100 \mathrm{~m}$, onde todos os indivíduos com DAP igual ou maior que 4,0 cm foram amostrados e identificados. Para regeneração natural foram amostrados $560 \mathrm{~m}^{2}$, subdivididos em 14 parcelas de $10 \times 4 \mathrm{~m}$. No estrato arbóreo foram amostrados 2.125 indivíduos, pertencentes a 34 familias, 80 gêneros e 113 espécies, com densidade total de 1.517 ind. ha- ${ }^{1}$. Na regeneração natural foram amostrados 196 individuos, distribuídos em 24 familias e 49 espécies, com densidade total de 3.500 plântulas.ha ${ }^{1}$. Luehea divaricata Mart., Actinostemon concolor (Spreng.) Müll. Arg. e Parapiptadenia rigida (Benth.) Brenan apresentaram os maiores Valores de Importância Ampliados (7,1\%, 7,0\% e 5,3\%, respectivamente). Actinostemon concolor obteve elevado valor de Regeneração Natural Relativa $(18,1 \%)$. O baixo percentual na regeneração natural de espécies como Luehea divaricata e Parapiptadenia rigida, respectivamente 3,7\% e 1,5\%, típicas das FED, pode representar um comprometimento de manutenção na comunidade. O estudo revelou a presença de espécies
\end{abstract}


exóticas com potencial invasor, como a Hovenia dulcis Thumb. Esses fatos apontam para importância da adoção de medidas de manejo, uma vez que o fragmento florestal estudado encontra-se sofrendo interferência antrópica, influenciando nos mecanismos de sucessão ecológica.

Palavras-chave: Fitossociologia; Ecologia florestal; Sucessão secundária.

\section{INTRODUCTION}

Seasonal Deciduous Forests (SDF) occur in regions with annual precipitation of less than $1,600 \mathrm{~mm}$ or in regions with intense cold, which results in more than $50 \%$ of leaf losses in trees of a forest (OLIVEIRA-FILHO et al., 2006).

Santa Catarina State, Brazil has undergone strong anthropic pressures, first with logging and subsequently due to the extensive agriculture. Currently, the urbanization process has provided significant changes in the relationships of the resources on the edge and inside forest(MOTTER; FIGUEIRÓ, 2010; GASPER etal., 2012; VIBRANS et al., 2013a; SEVEGNANI; SCHROEDER, 2013). However, the territory of Santa Catarina has the largest area of remaining Atlantic forest, which represents $16 \%$ of SDF (IBGE, 2013; VIBRANS et al., 2013b).

By the end of the last century, the researches on plant composition in the west of the state were still insufficient, even with some important initiatives, such as the "Flora Ilustrada Catarinense" (NEGRELLE; SILVA, 1992). From the Forest Floristic Inventory of Santa Catarina (FFISC), new efforts have contributed to broaden the knowledge about remaining forests (GASPER et al., 2012).

According to Freitas and Magalhães (2012), the study of the horizontal structure is concerned about the sociological analysis of the species in the distribution of a sinusiae. Nevertheless, only this type of approach could not be enough for allowing a true characterization of the order of ecological importance of the species (FINOL, 1971). Thus, in order to get a more appropriate picture for the community knowledge, it is necessary to incorporate the arrangement of species along the vertical gradient (FARIAS et al., 1994).

The vertical structure defines the arrangement of different strata of a plant community (FREITAS; MAGALHÃES, 2012). The uneven-aged heterogeneous forests generally present a decrease in the availability of light along the vertical profile toward the ground, with greater differentiation of niches (SOUZA; SOUZA,
2004; MORAIS et al., 2013). Therefore, through the forest vertical stratification study, it is possible to obtain more detail about the richness, diversity, growth and biomass production (POLISEL, 2013).

Natural regeneration allows the effective analysis to diagnose the conservation state of the fragment and the response to the management as it represents the set of individuals that can be recruited for the later successional stages (SILVA et al., 2010).

According to Silva et al. (2010), the knowledge of the forest structure, combined with the analysis of natural regeneration, has a great importance for the elaboration of restoration plans, conservation and management of forest fragments, ensuring the maintenance of the community and composition species characteristics. However, when applied to a temporal scale, it contributes to a better understanding about the level of ecological stability and forest restoration velocity (SILVA et al., 2010).

This study aimed to evaluate the structure (horizontal and vertical) and the regeneration state of a Seasonal Deciduous Forest fragment located in the Santa Catarina Midwest region.

\section{MATERIALS AND METHODS}

\subsection{Description of the study site}

The study was conducted in a SDF fragment located between the cities Piratuba and Ipira, Midwest of the Santa Catarina State ( $27^{\circ} 25^{\prime} 34^{\prime \prime} \mathrm{S}$ and $\left.51^{\circ} 47^{\prime} 18^{\prime \prime} \mathrm{W}\right)$. The municipalities of Piratuba and Ipira have a population density of 33 and 30 inhabitants per $\mathrm{km}^{2}$, respectively (IBGE, 2013). In Piratuba, the industrial activities related to the agribusiness contribute to $50.6 \%$ of the GNP; in Ipira, the service sector and agriculture account for more than $80 \%$ of this indicator (SEBRAE, 2010a; SEBRAE, 2010b).

The reginal climate is classified as Cfa, i.e., a temperate humid hot-summer climate (KÖPPEN, 1948). The monthly precipitation varies between 100 and 181 $\mathrm{mm}$ and the monthly average temperature ranges from 
$11^{\circ} \mathrm{C}$ to $20^{\circ} \mathrm{C}$, with the minimum monthly average amplitude from $6{ }^{\circ} \mathrm{C}$ to $16^{\circ} \mathrm{C}$ (May to July) and the maximum average from $18^{\circ} \mathrm{C}$ to $26^{\circ} \mathrm{C}$ (December to February) (SPINELLI, 2012).

The study site is a secondary fragment of vegetation with about 120 ha, which is bounded for both urban perimeter of the municipalities and small farms, mostly with activities related to poultry and/or pig production.

\subsection{Collection and data analysis}

To assess the parameters of the plant community structure, 14 plots of $10 \times 100 \mathrm{~m}\left(14,000 \mathrm{~m}^{2}\right)$ were used. In those plots, all trees with diameter at breast height $(\mathrm{DBH})$ greater than or equal to $4.0 \mathrm{~cm}$ were identified and their DBH and height values recorded. For the Natural Regeneration analysis, it was considered the individuals with DBH less than $4.0 \mathrm{~cm}$ and equal to or greater than $2.0 \mathrm{~cm}$ in each of the 14 subplots of $40 \mathrm{~m}^{2}(10 \times 4 \mathrm{~m})$, allocated in all transects, totaling $560 \mathrm{~m}^{2}$.

The botanical material was collected and identified in the field and subsequently had its identification confirmed using specialized literature and comparison with the Herbarium Collection of the Federal University of Santa Catarina (FLOR). The families were organized according to the Angiosperm Phylogeny Group III (2009).

The phytosociological parameters used in the horizontal structure analysis were the Relative Frequency (RF), Relative Density (RD), Relative Dominance (RDo) Coverage Value (CV) and Importance Value (IV) (MULLER DUMBOIS; ELLEMBERG, 1974).

To assess the sociological position of each species in the community, the population was divided into three strata of total height $\left(h_{j}\right)($ SOUZA; LEITE, 1993) as follows: lower stratum: $h_{j}<\left(h_{x}-1 S\right)$; middle stratum: $\left(h_{x}-1 S\right) \leq h_{j}<\left(h_{x}+1 S\right)$; and upper stratum: $h_{j} \leq\left(h_{x}\right.$ $+1 \mathrm{~S})$. Where $h_{x}$ is the average height of the sampled individuals, $\mathrm{S}$ is the standard deviation of the total height of the stratum $h_{j}$ and $h_{j}$ is the total height of the $\mathrm{j}$-th individual tree of the respective stratum.

The vertical stratification was obtained by using the estimates of Absolute Sociological Position ( $\mathrm{ASP}_{\mathrm{i}}$ ) and Relative Sociological Position $\left(\mathrm{RSP}_{\mathrm{i}}\right.$ ) per species (FINOL, 1971).

The Relative Natural Regeneration (RNR) was assessed by using the arithmetic average of Frequency,
Density and size relative class of regeneration for each species present in this compartment (FINOL, 1971).

The Expanded Importance Value (EIV) was calculated from the arithmetic average of $\mathrm{IV} \times(\mathrm{RF}+\mathrm{RD}+\mathrm{RDo})$ + RSP + RNR for each species (FINOL, 1971).

The parameter analyses of the forest structure were calculated by using the software Mata Nativa 2 (CIENTEC, 2006).

The similarity of species among the strata was analyzed using the Venn diagram, as proposed by Pinheiro and Durigan (2012).

\section{RESULTS}

It was sampled 2,125 individuals of the arboreal stratum in $14,000 \mathrm{~m}^{2}$, belonging to 34 families, 80 genera and 113 species (Table 1). The total density of arboreal individuals with $\mathrm{DBH} \geq 4.0 \mathrm{~cm}$ in the sampled fragment was 1,517 individuals ha ${ }^{-1}$.

The lower strata represented the trees with total height $\left(h_{j}\right)<3.67 \mathrm{~m}$, totaling 190 individuals $(8.4 \%$ of the total number of sampled species). The total density

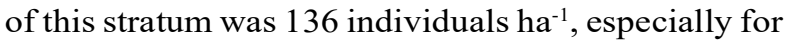
Actinostemom concolor (Spreng.) Müll. Arg. (15.3\%) (Figure 1).

The middle stratum included the range of heights between $3.67 \mathrm{~m} \leq \mathrm{h}_{\mathrm{j}}<9.24 \mathrm{~m}$, totaling 1,630 individuals (76.7\% of the total number of sampled plants), with a total density of 1,165 individuals $\mathrm{ha}^{-1}$. Luehea divaricata Mart., Actinostemon concolor and Casearia sylvestris Sw. were represented by the greatest number of individuals, with $7 \%$ each (Figure 1).

In its turn, the upper stratum included the trees with total height greater than or equal to $9.24 \mathrm{~m}$, totaling 305 individuals (14.3\%). The total density of this stratum was 218 individuals ha ${ }^{-1}$. The dominant species were Parapiptadenia rigida (Benth.) Brenan (9.5\%) and Ocotea puberula (Rich.) Nees (8.9\%) (Figure 1).

The analysis of Sociological Position (SP) showed that among the 113 species found, six were exclusive to the lower stratum, 35 to the middle stratum, three to the upper stratum and 72 common to all strata (Figure 1). In the lower stratum, the exclusive species were Celtis brasiliensis (Gardner) Planch., Myrciaria floribunda (H. West ex Willd.) O. Berg, Aloysia virgata (Ruiz \& Pav.) Pers. and others. Calyptranthes tricona D. Legrand, 


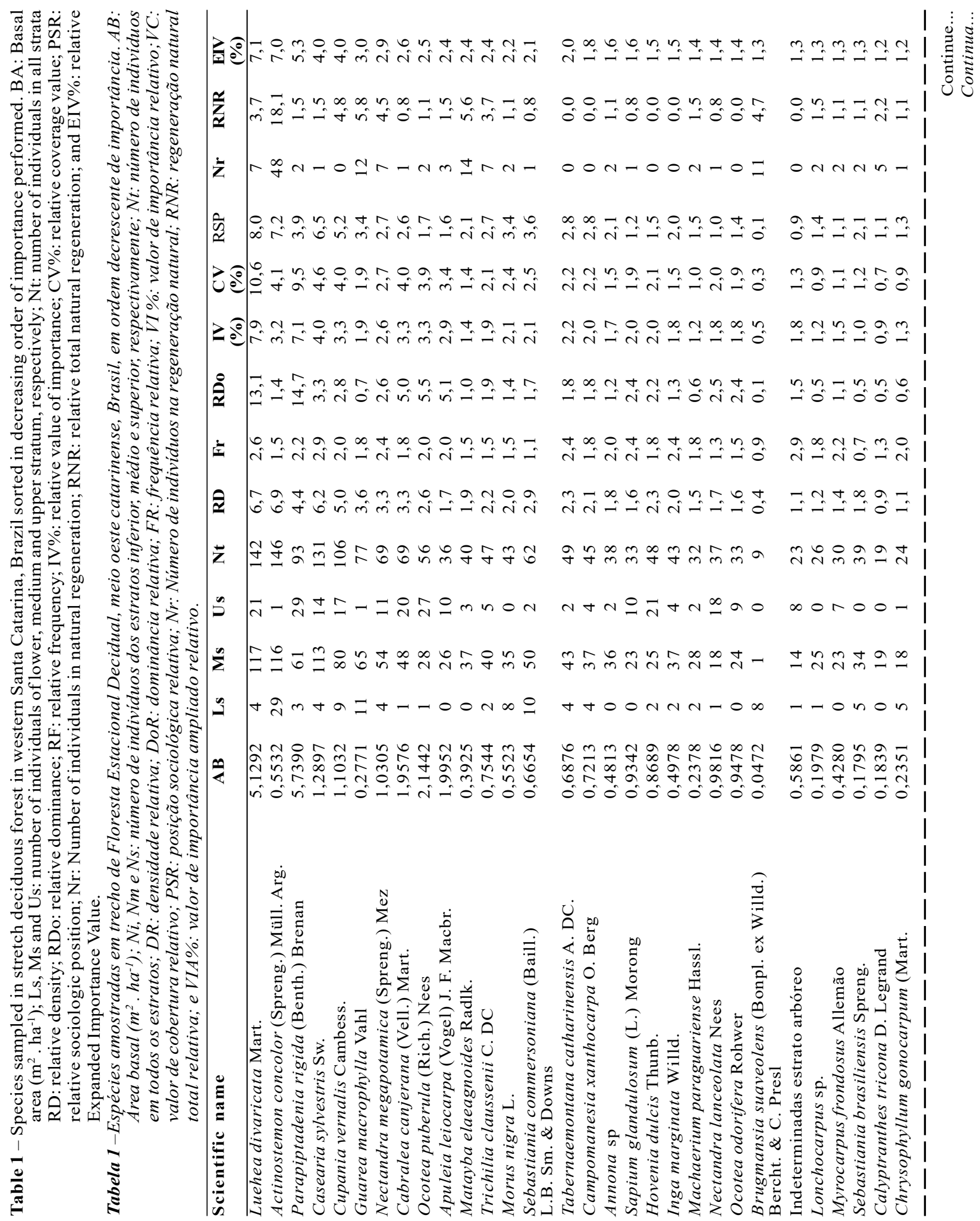

Revista Árvore, Viçosa-MG, v.40, n.5, p.781-791, 2016 


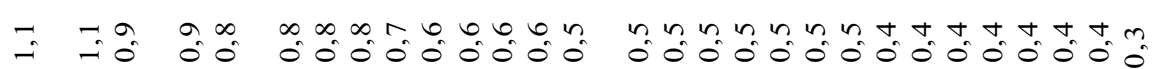

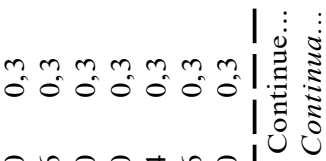

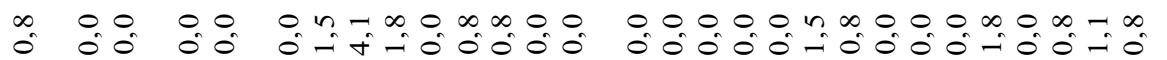

\begin{tabular}{ccccc|c|c}
0 & 0 & 0 & 0 & 0 & 0 & 0 \\
0 & 0 & 0 & 0 & 0 & 0
\end{tabular}

$-0$

$00-\infty 00-700,00000 m-000+0-n-1$

onoom no

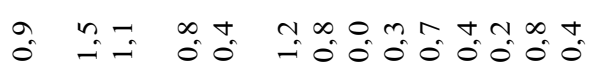

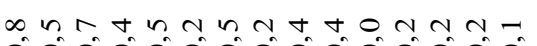

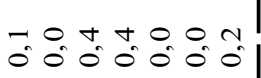

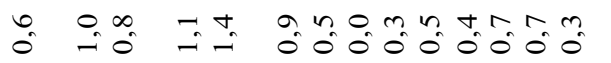

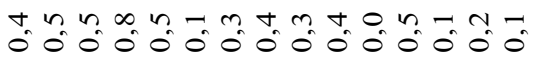

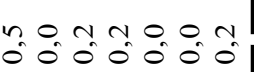

$\stackrel{n}{-}$

$\therefore m$ oñ

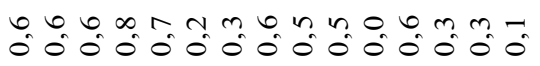

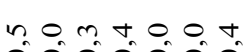

thr thrno-ningom

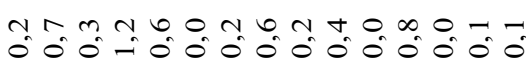

$\infty 0 n-0,0 h$

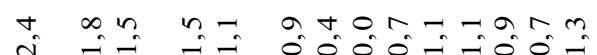

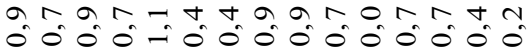

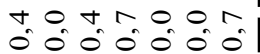

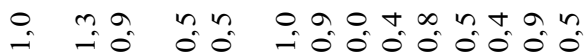

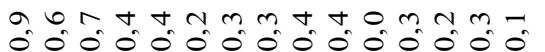

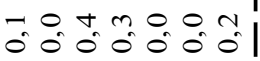

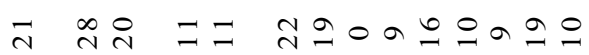

IItanonorabrtan

nom $00+$

- -

$4+-00-0-0 \mathrm{n} n$

$0-0 m n O 0 m-n O n O 0$,

noforom

$\stackrel{+}{\sim}$

$\infty \circ \cong n$ ก

$\stackrel{-}{-} \underline{-}$

- o $000 \mathrm{~m}$

n $n-h-\operatorname{trom} 0-00-$

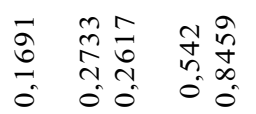

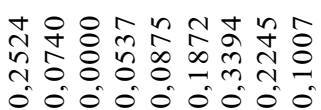

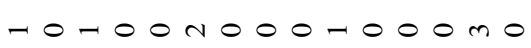

0000000

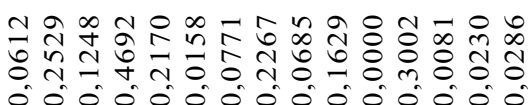

$\because \& \omega \pi \& \& \approx 1$

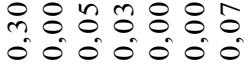
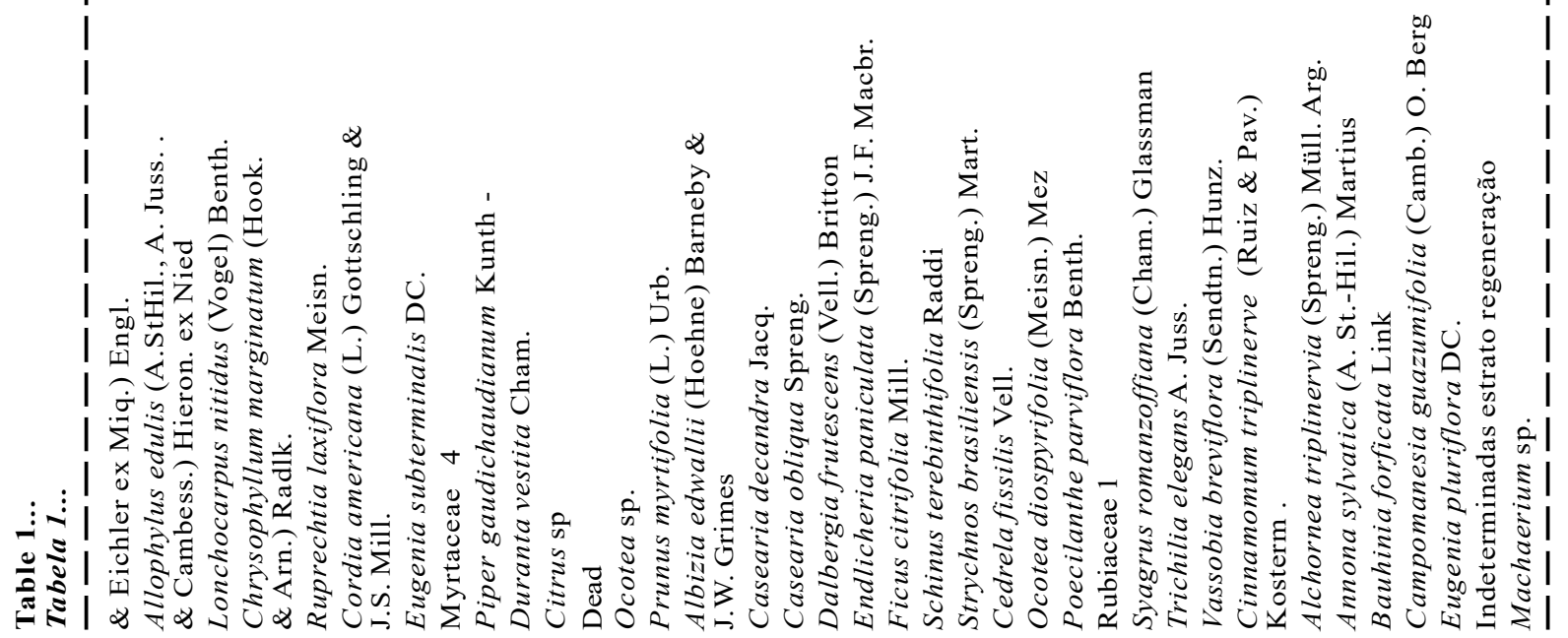

Revista Árvore, Viçosa-MG, v.40, n.5, p.781-791, 2016 


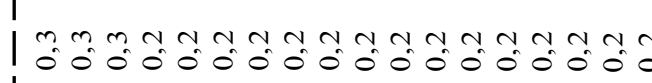

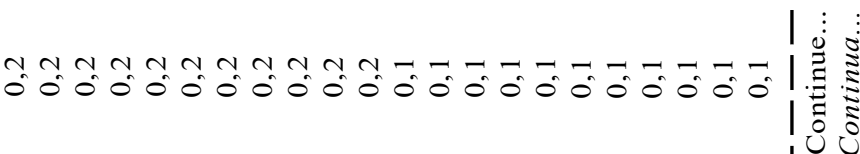

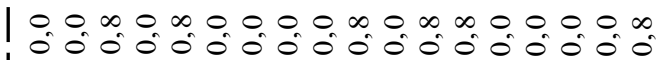

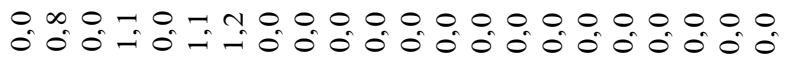
$100-0-0000-0-10000-$ $0-0 n 0 n n 0000000000000,0$

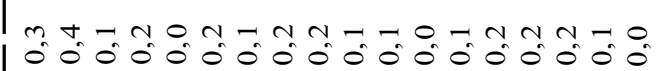

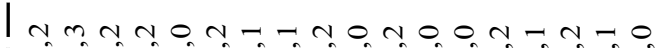

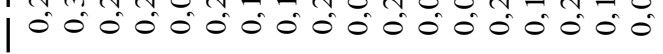
Itmmm-nhmm-mo-hnmn-

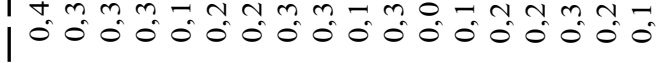

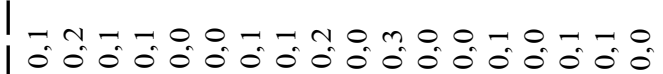
1

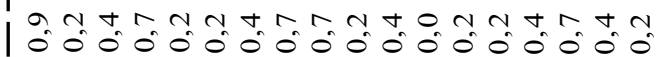
I

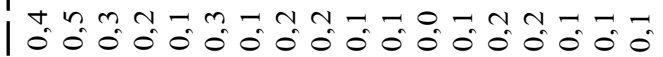
mont-omnt-40-mamn-

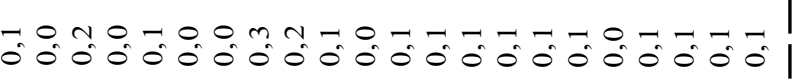

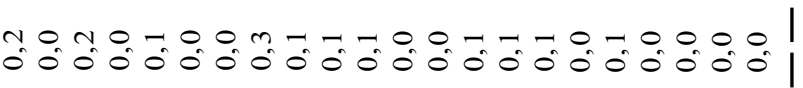

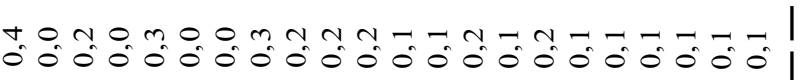

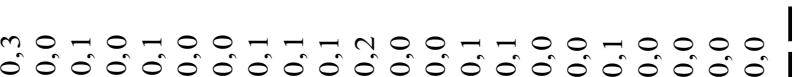

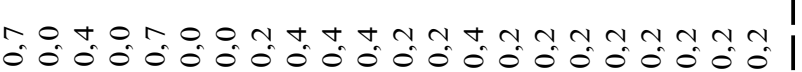

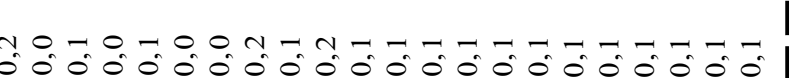
1.00000n000-0000-70 tomomoonnth-Thm-7h-7 no00000000no0-000-0000

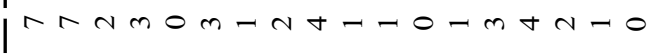

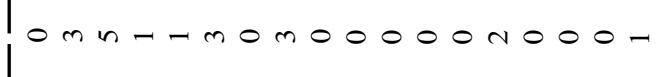

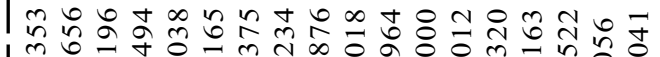

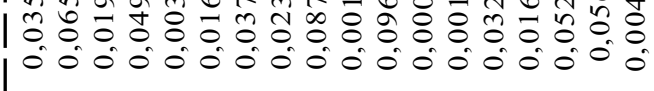

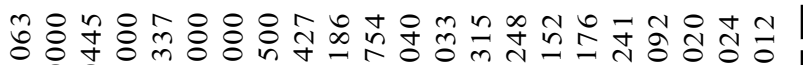

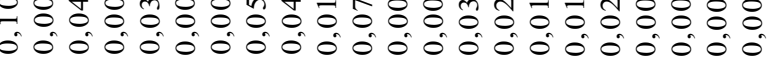
I

I $\quad-\quad$ च
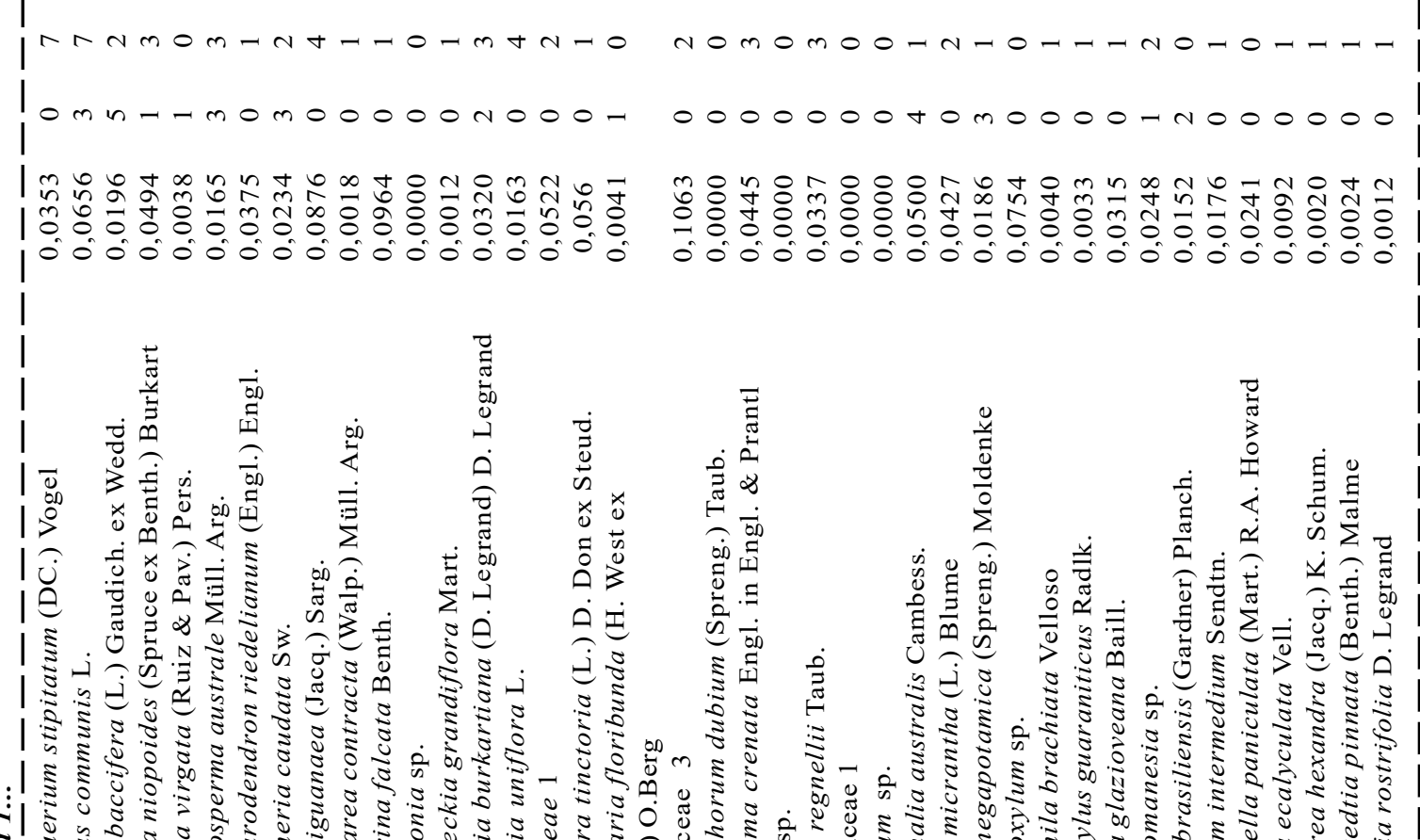

$0000000+0 m 0000-4000000$

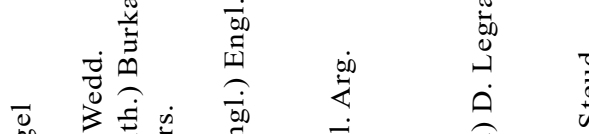

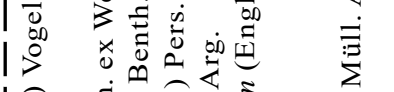

|

I $\equiv$.

$\sum \sqrt{1}$

官 $\dot{\theta} \dot{\theta}$

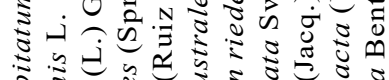

$\stackrel{0}{2}$

官过

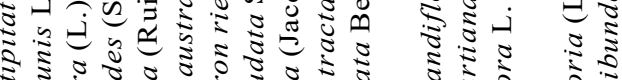

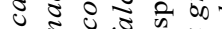




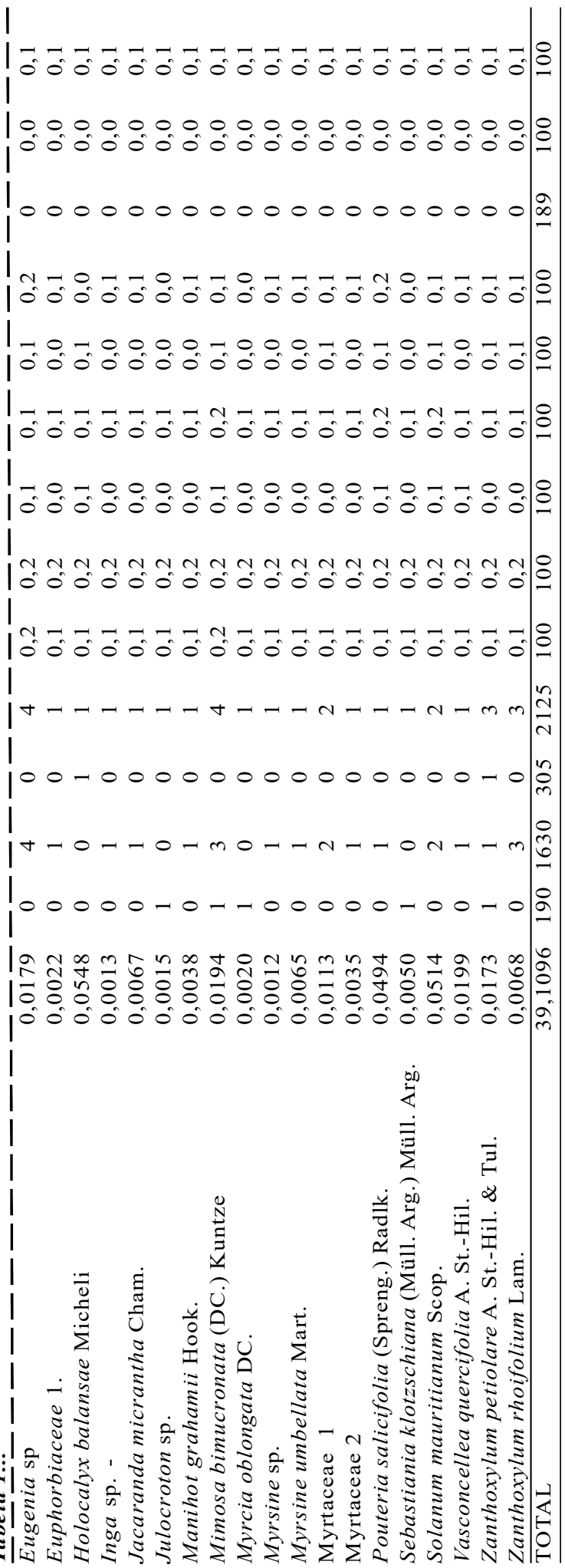

Bauhinia forficata Link and Campomanesia guazumifolia (Camb.) O. Berg occurred only in the middle stratum. On the other hand, Zanthoxylum sp., Holocalyx balansae Micheli and Citronella paniculata (Mart.) R.A. Howard were found only in the upper stratum.

The natural regeneration counted on 189 individuals distributed into 24 families and 49 species, in addition to the dead individuals (Table 1), with total density of 3,500 seedlings ha" ${ }^{\prime}$. Among the recruiters, the species that presented the highest value for natural regeneration was Actinostemon concolor (18.1\%), followed by Guarea macrophylla Vahl (5.8\%) and Matayba elaeagnoides Radlk (5.6\%). About $20 \%$ of the species occurred only in this compartment, especially Piper gaudichaudianum Kunth, Eugenia pluriflora DC., Annona sylvatica (A. St.-Hil.) Martius, Peltophorum dubium (Spreng.) Taub and others.

The EIV analysis pointed out that the species Luehea divaricata, Actinostemon concolor, Parapiptadenia rigida, Casearia sylvestris and Cupania vernalis Cambess. (Table 1) represent more than $25 \%$ of the total value of this parameter.

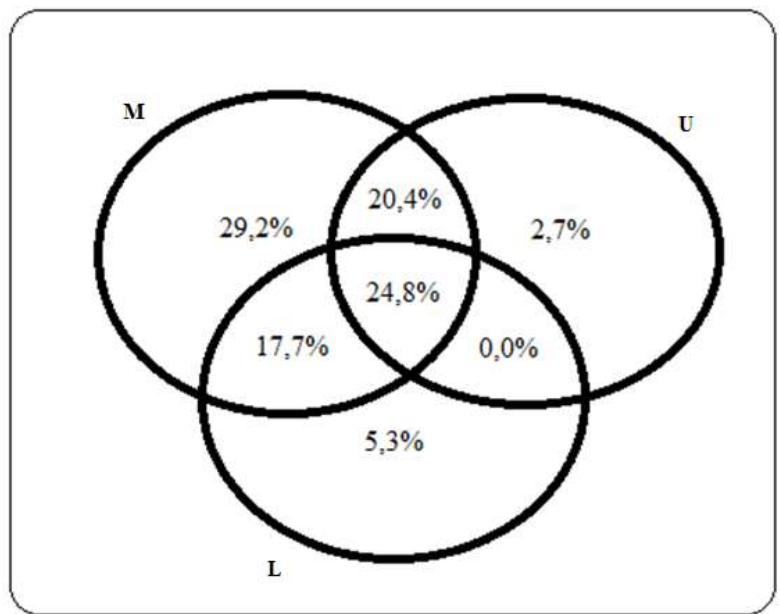

Figure 1 - Venn Diagram produced from exclusive and shared species among the three vegetation strata sampled in stretch deciduous forest in western Santa Catarina, Brazil. $\mathrm{I}=$ lower stratum; $\mathrm{M}=$ medium and Stratum; $\mathrm{S}=$ upper stratum.

Figura 1 - Diagrama de Venn produzido a partir das espécies compartilhadas e exclusivas entre os três estratos da vegetaçãoamostradosemum trechodeFlorestaEstacional Decidual, meio oeste catarinense, Brasil. I = Estrato inferior; $M=$ Estrato médio e; $S=$ Estrato superior.

Revista Árvore, Viçosa-MG, v.40, n.5, p.781-791, 2016 
The species Ocotea odorifera Rohwer is listed in the list of endangered species of the Brazilian Institute of Environment and Renewable Natural Resources in the State of Santa Catarina (BRASIL, 2008). The study showed the presence of just over $4 \%$ of exotic species, such as Cinnamomum triplinerve (Ruiz \& Pav.) Kosterm., Citrus sp., Hovenia dulcis Thunb. and Morus nigra L. and Brugmansia suaveolens (Bonpl. ex Willd.) Bercht. \& C. Presl (1.05\%) (FLORA BRASIL, 2014).

\section{DISCUSSION}

In the Atlantic forest, particularly in Seasonal Deciduous Forest formations, studies of floristic composition and arboreal stratum structure have been widely disseminated, especially during the last decades, in the Brazilian states of Rio Grande do Sul (SEMA/ UFSM-RS, 2001; JURINITZ; JARENKOW, 2003; LINDENMAIER; BUDKE, 2006) and Santa Catarina (GASPER et al., 2012; GASPER et al., 2013). However, researches involving the assessment of the vertical distribution of arboreal species in this region are still poorly developed, especially due to the difficulty of identifying the species in juvenile stages (POLISEL, 2013).

Since the last century, some studies have been contributing to a better understanding of phytogeographical and floristic attributes of SDFs. Prado and Gibbs (1993) reported a tenuous connection between the vegetation of the Caatinga and the Argentine Chaco through species that cross Brazil occurring in areas of seasonal forests of the Atlantic forest (Seasonal Forests of Central Brazil and the channel of the Uruguay River) and the Cerrado region. Most likely, this vegetation corridor has reached its maximum extent during the Pleistocene (dry and cold climate), which can be observed from the species widely distributed (RATTER et al. 1978; PRADO; GIBBS, 1993; OLIVEIRAFILHO;FONTES, 2000; PENNINGTON et al., 2000).

According to Moraes and Silva (2006), the more regular the distribution of individuals of a species in the vertical structure of a forest is, the higher its value in the Relative Sociological Position. This descriptor shows the importance of Luehea divaricata $(\mathrm{RSP}=$ $7.10 \%)$, Actinostemon concolor (7.00\%), Casearia sylvestris $(6.79 \%)$, Cupania vernalis $(4.93 \%)$ and Parapiptadenia rigida (3.91\%) in the studied community structure. These species were also well represented in other studies conducted in deciduous forests in southern Brazil (FARIAS et al., 1994; LONGHI et al., 2000).

The great abundance of Actinostemon concolor in the natural regeneration corroborates the study of Jurinitz and Jarenkow (2003) when observe that it is a shrubby species and inhabit the lower stratum and understory of SDF. Peltophorum dubium, Eugenia pluriflora and Annona sylvatica were recorded only in the natural regeneration probably due to the randomness used in allocating the sample units. The species Piper gaudichaudianum has a shrubby habit and is common in clearings and forest edges (BARDELLI et al., 2008). The increase in sampling effort could better clarify the meaning of these numbers.

Considering the species with the highest EIV, Luehea divaricata, Casearia sylvestris, Cupania vernalis, Guarea macrophylla Vahl and Cabralea canjerana (Vell.) Mart. are considered as "supertramps", i.e., species that are widely distributed in various phytophysionomies of forest in the Atlantic area in Brazil (OLIVEIRAFILHO; FONTES, 2000). The other five (Actinostemon concolor, Parapiptadenia rigida, Nectandra megapotamica (Spreng.) Mez, Ocotea puberula and Apuleia leiocarpa (Vogel) J. F. Macbr.) are pointed out by Fontana and Sevegnani (2012) as widely spread in the SDF of the state. Among the above species, only Actionostemom concolor has no entry problems in the community, since it is well represented in the lower stratum and natural regeneration (Table 1), which suggests the expansion of the sampling effort of the natural regeneration.

In Santa Catarina, Hovenia dulcis has been identified as an important exotic species with invasive potential, as observed in the Fritz Plaumann State Park, Concórdia, SC, Brazil (DECHOUM; ZILLER, 2013). In this study, this species presented a density in the middle and upper strata of respectively 18 individuals ha" 1 and 15 individuals ha" ${ }^{1}$. However, in the lower stratum this species presented only 2 individuals ha" ${ }^{1}$, which, at first sight, seems to corroborate the hypothesis of a problem associated with the invasion of species in the community. However, by observing the fragment as a whole, we observed a widespread occurrence of this species, both in the arboreal stratum and in regeneration. The presence of this species can be 
associated with plantation and/or restoration activities for multiple uses that occurred in the recent past or due to the process of randomness of sampling, since the species has a preference for habitats with higher solar radiation (heliophytic species), occupying forest edges and recent clearings (CARVALHO, 1994). The same applies to the exotic species Morus nigra L., abundant in the middle stratum, and Brugmansia suaveolensi, abundant in the natural regeneration (Table 1), which may cause problems of biological invasion in the future. The species Guarea macrophylla reached a moderate highlight in the regeneration (third place), in the lower stratum (second place) and in the middle stratum (fifth place). It is noteworthy that even native species, when considered dominants, may behave as invasive by some environmental disturbance, also requiring attention in the control and management of their populations (RICHARDSON et al., 2000). Thus, it is recommended to continue the study in order to assess the community dynamics compared to the possible effects of population dynamics of these species.

According to the CONAMA RESOLUTION from April, 1994 (BRASIL, 1994), which establish the succession stage of the Atlantic forest for the State of Santa Catarina. The forest structure of the fragment is in the successional stage from initial to medium, mostly due to the high value of basal area $\left(27.94 \mathrm{~m}^{2}\right.$ $\mathrm{ha}^{-1}$ ), but with anthropogenic interference signals in the floristic composition and in the recruitment of species in the community.

The results of this study can support important management measures for the fragment in question and others in the same physiographic condition. For example, the species Luehea divaricata (higher VI) could be used as anchor species for restoration models of forest fragments, resulting in a simpler and less costly strategy due to its greater adaptability to the current environmental conditions.

\section{CONCLUSIONS}

The main highlights in the horizontal structure were the species Luehea divaricata (142 individuals and $7.9 \%$ of IV) and Parapiptadenia rigida (93 individuals and $5.3 \%$ of IV). When the vertical structure were analyzed, it is possible to observe a low recruitment of these species, indicating problems in the regeneration possibly caused by anthropogenic changes. On the other hand, Actinostemon concolor takes the second place in terms of EIV (7.0\%) as a function of values obtained in its typical strata of occupation: natural regeneration (146 individuals), lower (29 individuals) and middle (116 individuals). In the community was also possible to identify the presence of exotic species with invasive potential (for example Hovenia dulcis). The presence of an endangered species (Ocotea odorifera) has been identified, in addition to others with economic potential (Apuleia leiocarpa and Cabralea canjerana), among species of high EIV. Given these facts, it is essential the implementation of management measures of forest fragments and the adoption of public policies aiming forest conservation in the region.

\section{REFERÊNCIAS}

ANGIOSPERM PHYLOGENY GROUP III. An update of the Angiosperm Phylogeny Group classification for the orders and families of flowering plants: APG III. Botanical Journal of the Linnaean Society, v.161, n.2, p.105-121, 2009.

BARDELLI, K.C.; KIRIZAWA, M.; SOUSA, A.V.G O gênero Piper L. (Piperaceae) da Mata Atlântica da Microbacia do Sítio Cabuçu-Proguaru, Guarulhos, SP, Brasil. Hoehnea, v.35, n.4, p.553561,2008

BRASIL. Resolução CONAMA No 004/1994, de 17 de junho de 1994. Diário Oficial [da] República Federativa do Brasil, Poder Executivo, Brasília, DF, 14 jun. 1997.

BRASIL. Instrução Normativa n. 6, de 23 de setembro de 2008. Dispõe sobre a Lista das espécies da flora brasileira ameaçada de extinção.

CARVALHO, P.E.R. Ecologia, silvicultura e usos da uva-do-japão (Hovenia dulcis Thunberg). Colombo: Embrapa-CNPFlorestas, 1994. $24 \mathrm{p}$.

CIENTEC. Software Mata Nativa 2: Sistema para Análise Fitossociológica, Elaboração de Inventários e Planos de Manejo de Florestas Nativas: manual do usuário. Viçosa, MG: CIENTEC, 2006.

DECHOUM, M.S.; ZILLER, S.R. Métodos para controle de plantas exóticas invasoras Biotemas, v.26, n.1, p.69-77, 2013.

Revista Árvore, Viçosa-MG, v.40, n.5, p.781-791, 2016 
FARIAS, J.A.C.; TEIXEIRA, I. F.; PES, L.S.; ALVAREZ FILHO, A.Estrutura fitossociológica de uma Floresta Estacional Decidual na região de Santa Maria, RS. Ciência Florestal, v.4, n.1, p.109-128, 1994.

FINOL, U.H. Nuevos parametros a considerarse en el analisis estrutural de las selvas virgenes tropicales. Revista Forestal Venezolana, v.18, n.12, p.29-42, 1971.

FLORA DO BRASIL. Lista de espécies da Flora do Brasil. Jardim Botânico do Rio de Janeiro. [acessado em 31 jul. 2014]. Disponível em: http://floradobrasil.jbrj.gov.br/2012.

FONTANA, C.; SEVEGNANI, L. Quais são as espécies arbóreas comuns da Floresta Estacional Decidual em Santa Catarina? REA - Revista de Estudos Ambientais, v.14, n.1, p.74-88, 2012.

FREITAS, W.K.; MAGALHAES, L.M.S. Métodos e parâmetros para estudo da vegetação com ênfase no estrato arbóreo. Floresta e Ambiente, v. 19, n.4, p.520-539, 2012.

GASPER, A.L.; UHLMANN, A.; VIBRANS, A.C.; SEVEGNANI, L.; MEYER, L. Grupos florísticos estruturais da Floresta Estacional Decidual em Santa Catarina. In: VIBRAN, SEVEGNANI, L.; GASPER A. L.; LINGNER, D. V.. Inventário Florístico Florestal de Santa Catarina - Floresta Estacional Decidual. Blumenau: EDIFURB, 2012. v.2. p.129-140.

GASPER, A.L.UHLMANN, A.; SEVEGNANI, D.; LINGNER, L.V.; RIGON-JÚNIOR, M.J.; VERDI, M.; STIVAL-SANTOS, A.; DREVECK, S.; SOBRAL, M.; VIBRANS, A.C. Inventário Florístico Florestal de Santa Catarina: espécies da Floresta Estacional Decidual. Rodriguésia, v.64, n.3, p.427-443, 2013.

\section{INSTITUTO BRASILEIRO DE GEOGRAFIA E} ESTATÍSTICA - IBGE. IBGE Cidades [acessado em: 21 abr. 2013]. Disponível em: http:// www.cidades.ibge.gov.br/xtras/home.php.

JURINITZ, C.F.; JARENKOW, J.A. Estrutura do componente arbóreo de uma floresta estacional na Serra do Sudeste, Rio Grande do Sul, Brasil. Revista Brasileira de Botânica, v.26, n.4, p.475-478, 2003.

Revista Árvore, Viçosa-MG, v.40, n.5, p.781-791, 2016
KÖPPEN, W. Climatologia: con un estudio de los climas de la tierra. México: Fondo de Cultura Econômica, 1948.

LINDENMAIER, D.S.; BUDKE J.C. Florística, diversidade e distribuição espacial das espécies arbóreas em uma floresta estacional na Bacia do Rio Jacuí, Sul do Brasil. Pesquisas Botânicas, n.57, p.193-216, 2006.

LONGHI, S.J ARAUJO, M. M.; KELLING, M. B.; HOPPE, J. M.; MÜLLER, I.; BORSOI, G. A. Aspectos fitossociológicos de fragmento de Floresta Estacional Decidual, Santa Maria, RS. Ciência Florestal, v. 10, n.2, p.59- 74, 2000.

MORAES E SILVA, V.S. Manejo de florestas nativas: planejamento, implantação e monitoramento. Cuiabá: UFMT, 2006.

MORAIS, R.F.; SILVA, E.C.S.; METELO, M.R.L.; MORAIS, F.F. Composição florística e estrutura da comunidade vegetal em diferentes fitofisionomias do Pantanal de Poconé, Mato Grosso. Rodriguésia, v.64, n.4, p.775-790, 2013.

MOTTER, A.F.C.; FIGUEIRÓ, A.S. Um olhar sobre o processo de transformação da paisagem na bacia do rio Santa Rosa (NW do RS), de 1915 até os dias atuais. Geografia: Ensino \& Pesquisa, v.14, n.1, p.01-08, 2010.

MUELLER-DOMBOIS, D.; ELLENBERG, H. Aims and methods of vegetation ecology. New York: John Wiley \& Sons, 1974.

NEGRELLE, R.A.B.; SILVA, F.C. Fitossociologia de um trecho de floresta com Araucaria angustifolia (Bert.) O. Ktze. no município de Caçador-SC.

Boletim de Pesquisa Florestal, n.24/25, p.37-54, 1992.

OLIVEIRA FILHO, A.T.; FONTES, M.A.L. Patterns of floristic differentiation among Atlantic forests in southeastern Brazil and the influence of climate. Biotropica, v.32, p.793-810, 2000.

OLIVEIRA FILHO, A.T.; JARENKOW, J.A.; RODAL, M.J.N. Floristic relationships of seasonally dry forests of eastern South America based on tree species distribution patterns. In: PENNINGTON, R.T.; LEWIS, G.P.; RATTER, J.A. (Orgs.). Neotropical savannas and dry 
forests: plant diversity, biogeography and conservation. Boca Raton: CRC Press, 2006. p.159-192.

PENNINGTON, R.T.; PRADO, D.A.; PENDRY, C. Neotropical seasonally dry forests and Pleistocene vegetation changes. Journal of Biogeography, v.27, p.261-273, 2000.

PINHEIRO, E.S.; DURIGAN, G. Diferenças florísticas e estruturais entre fitofisionomias do cerrado em Assis, SP, Brasil. Revista Árvore, v.36, n.1, p.181-193, 2012.

POLISEL R.T. Levantamento fitossociológico e caráter sucessional de um trecho de floresta secundária ciliar em Juquitiba, SP. Revista Árvore, v.37, n.5, p.789-799, 2013.

PRADO, D.E.; GIBBS, P.E. Patterns of species distributions in the dry forests of South America. Annals of the Missouri Botanical Garden, v.80, p.902-927, 1993.

RATTER, J.A.; RICHARDS, P.W.; ARGENT, G.; GIFFORD, D.R. Observations on the forests of some mesotrophic soils in central Brazil. Revista Brasileira de Botânica, v.1, p.47-58, 1978.

RICHARDSON, D.M.; PYSEK, P.; REJMANEK, M.; BARBOUR, M.G.; PANETTA, D.; WEST, C.J. Naturalization and invasion of alien plants: concepts and definitions. Diversity and Distributions, v.6, p.93-107, 2000.

SEBRAE. Santa Catarina em Números: Ipira. Florianópolis: 2010b. 112p.

SEBRAE. Santa Catarina em Números: Piratuba. Florianópolis: 2010a. 115p.

SEMA/UFSM-RS. Relatório final do inventário florestal contínuo do Rio
Grande do Sul. Porto Alegre: Governo do estado do Rio Grande do Sul, 2001.

\section{SEVEGNANI, L.; SCHROEDER, E. \\ Biodiversidade catarinense: \\ características, potencialidades, ameaças. \\ Blumenau: EDIFURB, 2013.}

SILVA, W.C.; MARANGON, L.C.; FERREIRA, R.L.C.; FELICIANO, A.L.P.; APARÍCIO, P.S.; COSTA JUNIOR, R.F. Estrutura horizontal e vertical do componente arbóreo em fase de regeneração natural na mata Santa Luzia, no município de Catende-PE. Revista Árvore, v.34, n.5, p.863- 869, 2010.

SOUZA, A.L.; LEITE, H.G. Regulação da produção em florestas ineqüiâneas. Viçosa, MG: Universidade Federal de Viçosa, 1993.

SOUZA, D.R.; SOUZA, A.L. Estratificação vertical em floresta ombrófila densa de terra firme não explorada, Amazônia Oriental. Revista Árvore, v.28, n.5, p.691-698, 2004.

SPINELLI, K. Variabilidade pluviométrica na bacia rio do Peixe - Santa

Catarina. 2012. 195f. Dissertação (Mestrado em Geografia) - Universidade Federal de Santa Catarina, Florianópolis, 2012.

VIBRANS, A.C.; SEVEGNANI, L.; GASPER, A.L..; MÜLLER, J.J.V.; REIS, M.S. Inventário florístico florestal de Santa Catarina: resultados resumidos. Blumenau: FURB / CCAUFSC / Epagri, 2013a. 37p.

VIBRANS, A.C; MCROBERTS, R.E.; MOSER, P.; NICOLETTI, A.L. Using satellite image-based maps and ground inventory data to estimate the remaining Atlantic forest in the Brazilian state of Santa Catarina. Remote Sensing of Environment, v.130, p.87-95, 2013b 